\title{
The Battle of Britain: History and Reformation in Early Modern Wales
}

\author{
Lloyd Bowen
}

The Welsh of the sixteenth and seventeenth centuries were proverbially proud of their history. They saw themselves as the descendents of the Ancient Britons who had dominion over these islands long before the arrival of the Romans. This Welsh heritage itself had a long lineage by the time the Tudors came to the throne, appearing in one form in the Armes Prydain (The Prophecy of Britain) in the early tenth century. It was most successfully synthesised by one of their own, Geoffrey of Monmouth, whose Historia Regum Britanniae (c.1136) encapsulated both the majesty of the Welsh people's distant past, but also foretold their restitution to former glories by the mab darogan ('son of prophecy') who would deliver them from Saxon bondage and restore their authority over Britain. The Welsh became the staunchest and most vociferous supporters of the whole corpus of the Galfridian tradition after it came under attack by humanist scholars such as Polydore Vergil and Hector Boece in the early sixteenth century. ${ }^{1}$ They were obsessed with a particular vision of the past, and this was to prove an important vehicle for conveying the Protestant Reformation to them. The story of Reformation in Wales is bound up with issues of state building and the country's incorporation within the English polity, but it is also a narrative of cultural accommodation on the part both of the Welsh and the Crown. This accommodation took the form of translation of the scriptures and prayer book into Welsh, but this vernacularisation was inflected with another element designed to

\footnotetext{
${ }^{1}$ Brinley Roberts, 'Geoffrey of Monmouth and Welsh Historical Tradition', Nottingham Medieval Studies, 20 (1976), 29-40; J. B. Smith, The Sense of History in Medieval Wales (Aberystwyth, 1989); Ieuan M. Williams, 'Ysgolheictod Hanesyddol yr Unfed Ganrif ar Bymtheg', Llên Cymru, 2 (1952-3), 111-24, 209-23; A. H. O. Jarman, Geoffrey of Monmouth: Sieffre o Fynwy (Cardiff, 1966), especially 96-111; G. M. Griffiths, 'John Lewis of Llynwene's Defence of Geoffrey of Monmouth's "Historia", National Library of Wales Journal, 7 (1951-2), 228-34.
} 
inculturate the Reformation in Wales - the identification of Protestantism with the Welsh past.

Much of the secondary literature dealing with these issues has shown how different readings of early church history were used in doctrinal and theological defences of the Church of England, but few have recognised the centrality of early British history to contemporary notions of Welshness. ${ }^{2}$ They have also largely failed to explore how the Reformation was particularly successful in blending Welshness, Britishness and the primitive church as a rediscovery of a lost Welsh faith. This essay offers a discussion of how religious history was employed and disputed within a Welsh context in the sixteenth and early seventeenth centuries. It will show how, in many respects, the Reformation in Wales was particularly historical in nature and drew upon considerable reserves of patriotic capital there. It will also discuss how Welsh Catholics and puritans, like their 'Anglican' counterparts, attempted to appropriate the early history of the Welsh church to support their claims to authority and legitimacy. The chapter also reflects on the continued potency of such sacred history in Wales when it had largely been forgotten or discredited in England.

\section{II}

The progress of Reformation in Wales was slow, halting and tortuous. There was no rebellion against the religious changes there, no Pilgrimage of Grace, but neither was there any real sign of enthusiasm for the new faith, and contemporaries were acutely aware of the discontented grumblings and Catholic sympathies which

\footnotetext{
${ }^{2}$ Exceptions include Glanmor Williams, 'Some Protestant Views of the Early British Church' in idem, Welsh Reformation Essays (Cardiff, 1967), pp. 207-19; Peter Roberts, 'Tudor Wales, National Identity and the British Inheritance' in idem and Brendan Bradshaw (eds), British Consciousness and Identity: The Making of Britain, 1533-1707 (Cambridge, 2003), pp. 8, 14-19; Philip Schwyzer, Literature, Nationalism and Memory in Early Modern England and Wales (Cambridge, 2004).
} 
remained strong throughout the sixteenth century. ${ }^{3}$ Hostile Catholic powers saw Wales as a potential ally in any move against its Protestant prince, and more than once it was mooted by foreign agents as a possible invasion site. In 1571 a papal agent wrote that Wales was 'a stronghold of the Catholics', while an exiled Welsh Catholic, Morys Clynnog, could inform the Pope in 1575 that '[Wales is] most devoted to the Catholic faith, and most inclined to welcome aid from abroad for the restoration of religion'. Despite their indifference to the new faith, the Welsh acquiesced in the religious changes of the 1530s and 1540s in no small measure because of the contemporaneous benefits the local gentry obtained by incorporation with England through the Acts of Union (1536-1543). ${ }^{5}$ There was indulgence of Catholicism on the part of most governors rather than any zeal for religious change. Indeed, the bishop of St Davids, Richard Davies, was scathing about the indifferent lead the Welsh gentry had given the people in his funeral sermon for the earl of Essex at Carmarthen in 1577. ${ }^{6}$ Davies's irritation stemmed from the glacial pace of reform in the principality which troubled both lay and ecclesiastical officials. In a report on the diocese of Bangor three decades after the break with Rome, the bishop, Nicholas Robinson, described the pervasive 'ignorance' there and spoke of 'the dregs of superstition', with images and altars undefaced, vigils and pilgrimages continuing 'and all the country full of knots and beads'. ${ }^{7}$ The situation was similar in the three other Welsh dioceses.

\footnotetext{
${ }^{3}$ For this see Glanmor Williams, Wales and the Reformation (Cardiff, 1997).

${ }^{4}$ G. Dyfnallt Owen, Elizabethan Wales: The Social Scene (Cardiff, 1964), 221; J. M. Cleary, 'Dr Morys Clynnog's Invasion Projects', Recusant History, 8 (1965), 305.

${ }^{5}$ Peter Roberts, 'The Union with England and the Identity of "Anglican" Wales', Transactions of the Royal Historical Society, $5^{\text {th }}$ series, 22 (1972), 49-70.

${ }^{6}$ Richard Davies, A Funerall Sermon ... at the Buriall of ... Walter Earle of Essex (London, 1577), sigs. Dii-Diii.

7 David Matthew (ed.), 'Some Elizabethan Documents', Bulletin of the Board of Celtic Studies, 6 (1953), 77-8.
} 
The need for security against Catholic invasion and the nature of the union settlement meant it was essential that the unresponsiveness of the Welsh towards the new faith be addressed. The nature of the problem facing central government and local reformers encouraged them to consider framing particularist solutions which took account of Welsh cultural distinctiveness. English Protestantism was presented to the Welsh in a language as incomprehensible as Latin, closed up 'from the people in an unknown tongue', while it was also perceived by many as a foreign imposition by the old enemy, ' $y$ ffydd Saeson' ('the faith of the Saxons') as the Glamorgan bard Thomas ab Ieuan ap Rhys put it. ${ }^{8}$ From comparatively early on, then, Welsh reformers emphasised the need to translate the Scriptures and prayer book into Welsh, but running parallel with this was an attempt to naturalise Protestantism in Wales through patriotic appeals to their cherished history. Indeed, it is perhaps artificial to separate the two as Welsh reformers, like many of their colleagues in England, believed that the early Britons had possessed all of holy scripture in their own language, Welsh, before the coming of Roman corruptions. ${ }^{9}$ Translation, then, would not only be a means of communicating Protestantism to the people, it would also be an exercise in linguistic archaeology and an imaginative restoration of a lost historical text. This combined appeal to language and history is a continuing theme of religious reform in early modern Wales.

Some excellent work has recently appeared on the uses of early British history in the English Reformation. ${ }^{10}$ This has developed subtle readings of the uses to which

\footnotetext{
${ }^{8}$ Matthew, 'Some Elizabethan Documents', 77; Glanmor Williams (ed.), Glamorgan County History, 4: Early Modern Glamorgan (Cardiff, 1974), pp. 218-19.

${ }^{9}$ Welsh scholars argued well into the eighteenth century that the Welsh language was closely affiliated with Hebrew, and that it had 'received no alteration at Babel': Colin Kidd, British Identities before Nationalism: Ethnicity and Nationhood in the Atlantic World (Cambridge, 1999), p. 69.

${ }^{10}$ Benedict Scott Robinson, "Darke Speech": Matthew Parker and the Reforming of History', Sixteenth Century Journal 29 (1998), 1061-83; Kidd, British Identities, pp. 99-122; Felicity Heal, 'Appropriating History: Catholic and Protestant Polemics and the National Past' and John Spurr "“A Special Kindness for Dead Bishops": The Church, History and Testimony in Seventeenth-Century
} 
history was put in defending and justifying the reformed church in England. Central to this story has been the ways in which reformers utilised the history of the primitive British church to underpin arguments for the continuity and purity of the Church of England. Establishing the apostolic primacy of the reformed church was vital to counter the Catholic argument that the Reformation was a new fangled heresy, a creation of man rather than the work of God. Drawing on authorities like Gildas, Bede and Geoffrey of Monmouth, Protestant scholars like John Bale developed a narrative of the early British church which emphasised its independence and uncorrupted purity. One strand gave particular prominence to the conversion of King Lucius in the second century, after which there developed a pristine church with metropolitans at London, York and Caerleon. Another dwelt on the mission of Joseph of Arimathea who introduced the uncorrupted Christian faith to the Britons only decades after Christ's death and resurrection. These narratives demonstrated how Augustine's mission to Kent in 597 did not represent the conversion of the British but rather the introduction of Roman corruptions by the Saxons. It was only as the Romanised Saxons gained dominion over the Britons, the genealogical and spiritual forefathers of the Welsh, that they fell into error and darkness. The Reformation was presented as showing the way back to the pure faith which was once universal. Such a tale cast the Saxon progenitors of the English as the villains of the piece, while the ancestors of the Welsh were the heroes keeping the flame of the true gospel alive until wickedness and treachery did for them. Given the history of Welsh subjugation by the Anglo-

Protestantism', both in Huntington Library Quarterly, 68:2 (2005), 109-32, 313-34; Felicity Heal, 'What can King Lucius do for you? The Reformation and the Early British Church', English Historical Review, 120 (2005), 593-614; Alan MacColl, 'The Construction of England as a Protestant "British" Nation in the Sixteenth Century', Renaissance Quarterly, 18 (2004), 582-608; David Weil Baker, 'The Historical Faith of William Tyndale: Non-Salvic Reading of Scripture at the Outset of the English Reformation', Renaissance Quarterly, 62 (2009), 661-92. 
Normans and English, the appeal of such a model for the Welsh of the sixteenth and seventeenth centuries was obvious.

III

The English Reformation was deeply historical, but the Reformation in Wales was perhaps even more so, and its people were particularly primed to respond to such appeals. ${ }^{11}$ The legend of Britain was a potentially fruitful agent for carrying the Reformation forward in Wales as it touched on cherished ideas about identity, historicity, precedence and renewal, and the most influential reformers in the principality sought to incorporate a patriotic vision of religious history alongside their lobbying efforts for the vernacularisation of the Scriptures. A central figure in this was William Salesbury (c.1520-80), a towering Renaissance scholar and polemicist who had command of Welsh, Hebrew, Greek, Latin, English, French, German 'and other languages'. ${ }^{12}$ Salesbury was an indefatigable campaigner for the need to address the spiritual needs of his countrymen. ${ }^{13}$ He wrote a number of tracts in the midsixteenth century which showed his commitment to reform and his loyalty to the Crown. In 1547 he produced Oll Synnwyr Pen Kembro Ygyd ('The Whole Sense of a Welshman's Head') which collected the proverbs of Gruffudd Hiraethog, a notable Welsh bard and a friend of Salesbury. Salesbury's introduction to this work dwelt on the necessity of translating the Bible into Welsh. Alongside this plea, however, he also touched on an issue which resonated with many of his listeners - the history of Welsh faith. His was a polemical argument which married the cause of reform with a genuine sense of Welsh patriotism. Salesbury appealed to his readers to persuade the

\footnotetext{
${ }^{11}$ Matthew Sutcliffe, The Subversion of Robert Parsons (London, 1606), sig. A2.

${ }^{12}$ R. Brinley Jones, 'Salesbury, William (b. before 1520, d. c.1580)', Oxford DNB.

${ }^{13}$ Important discussions of Salesbury include Glanmor Williams, 'The Achievement of William Salesbury', in idem, Welsh Reformation Essays, pp. 191-206, and R. Brinley Jones, William Salesbury (Cardiff, 1994).
} 
king to allow translation of the scriptures, arguing 'unless you wish utterly to depart from the faith of Christ ... obtain the holy scripture in your tongue as your fortunate ancestors, the ancient British had it'. ${ }^{14}$ Once the Welsh had lost the faith of their ancestors, so their language degraded and God 'caused them to be called alien and foreign in the land of their birth'. Salesbury rendered this fate as 'the remains of God's curse since the time of Cadwaladr the Blessed'. This was, then, a Galfridian trajectory, drawing on the passage in the Historia where an angel revealed to Cadwaladr that the Britons (the modern Welsh) would lose their kingdom, but also the prophecy which foretold of rebirth and regeneration when, 'as a reward for its faithfulness, the British people would occupy the island again'. ${ }^{15}$ Indeed, it is telling that the material in Oll Synnwyr was reprinted in a publication of 1567 along with Trioedd Ynys Prydein (Triads of the Island of Britain), medieval Welsh poems which dilated on the country's ancient heroes, and which had some overlap with Geoffrey's Historia. $^{16}$

Geoffrey's model propagated a potentially anti-English discourse, with the Welsh being vanquished by Saxon invaders from their rightful land - indeed Owain Glyndwr had used this tradition to rally Welsh sentiment against the English. ${ }^{17}$ There are echoes of this in Salesbury's reference to the Welsh being called foreigners in their own land. ${ }^{18}$ The word 'Welsh' was derived from the Old English Wealh which meant 'foreigners', and Salesbury here seems to be trying deliberately to invoke such

\footnotetext{
${ }^{14}$ William Salesbury, Oll Synnwyr Pen Kembro Ygyd (London, 1547), translation in J. G. Jones (ed.), Wales and the Tudor State (Cardiff, 1989), pp. 238-9.

${ }^{15}$ Geoffrey of Monmouth, The History of the Kings of Britain ed. Lewis Thorpe (Harmondsworth, 1966), p. 283.

${ }^{16}$ Jones, William Salesbury, p. 21.

${ }^{17}$ On this see Glanmor Williams, 'Prophecy, Poetry and Politics in Medieval and Tudor Wales' in idem Religion, Language and Nationality in Wales (Cardiff, 1979), pp. 71-86; Rees R. Davies, The Revolt of Owain Glyn D̂̂r (Oxford, 1995), pp. 158-73.

${ }^{18}$ Cf. William Salesbury, A Briefe and Playne Introduction, Teachyng How to Pronounce the Letters of the British Tong (London, 1550), sig. E.iii r-v.
} 
familiar threads of the Galfridian tale. ${ }^{19}$ However, the oppositional element of this rhetoric was reconfigured into one of spiritual unification and recovery, as the Reformation was really a rediscovery of the faith of the Britons. The route back to belonging was through the true religion in their native tongue: 'if you wish to renounce that ancient and long-standing curse ... Make a bare-footed pilgrimage to His Grace the King and his Council to pray for permission to obtain the holy scripture in your own tongue'. This synthesis of history, religion and national identity was forcefully summarised in Salesbury's conclusion that if the Welsh people did not honour God by obtaining the scriptures in Welsh 'none of you can claim connection with British patriotism, nor be related to its various achievements and its good qualities'.

This was a message designed to appeal to popular sentiment in Wales. Salesbury placed it in a book of proverbs from one of the most famous poets of his day, he wrote it in the vernacular and the book was in the accessible black-letter typeface. The message regarding the particular historicity of the Welsh faith was made authoritatively in prose suffused with passion and pride, and which was intimately connected with issues of language, culture and nationhood. Salesbury believed that there was polemical and rhetorical mileage in fusing the British History of the Welsh with the reformed faith, and evidently considered this to be a popular perspective.

There is certainly evidence to support the view that Welsh history was a route into the popular consciousness, and contemporaries acknowledged that forms of the Welsh Galfridian tradition enjoyed a currency outside of academic circles. In

\footnotetext{
${ }^{19}$ Huw Pryce, 'British or Welsh? National Identity in Twelfth-Century Wales', English Historical Review, 116 (2001), 775-801. See also Humphrey Lhuyd's comment that 'the Welshmen themselves doo not understand what these words "Wales" and "Welsh" doo signifie, nor know anie other name of their countrie of themselves but Cambry, nor of their language but Cambraec': [David Powel], The Historie of Cambria, Now Called Wales (London, 1584). p.4 .
} 
Carmarthen in April 1550, for example, the Bishop of St Davids, Robert Ferrar, 'p[er]ceyvinge hym self to be evell beloved yn that countrey and utterly owte of credence with the people there', looked to flatter them by invoking their history. He claimed that the Welsh were more gentle than the English 'and no marvayle for sumtyme ye wer[e] Britaines and had this realme yn govern[an]ce, and yf the prophesye of Merlyn be true, ye shall so have it agayne'. ${ }^{20}$ In October 1600 Lodowic Lloyd could write to Secretary Robert Cecil that 'the old Romans were not as addicted to their sybils, the Egyptians to the priests of Memphis, nor the Frenchmen to their superstitious druids as many in my country are given to the prophecies of Merlin'. ${ }^{21}$ The sense of a distinctive history which swirled in a rather inchoate way around the cardinal points of Geoffrey's Historia seems to have been present at all levels of Welsh society. Salesbury's invocation of the Ancient Britons in the context of a reforming message was designed to connect these elements together in a way that appealed to the cultural predispositions of his readers and auditors.

\section{IV}

In 1551 Salesbury produced a Welsh version of the epistles and gospel readings authorised by the 1549 Book of Common Prayer, Kynniver Llith a Ban ('As Many Lessons and Articles') which represented an important step on the path to his ultimate goal of obtaining official sanction to translate the Bible into Welsh. He was probably part of the team which successfully lobbied for the act of parliament of 1563 which authorised this work - a milestone in the inculturation of the Reformation in

\footnotetext{
${ }^{20}$ British Library, Harleian MS 420, fo. 90. Ferrar was appealing to a local tradition as well as the broader British History here. Geoffrey of Monmouth placed Merlin's birth near the town, and its Welsh form, Caerfyrddin was interpreted as 'Merlin's Castle': A. H. O. Jarman, 'The Legend of Merlin and its Associations with Carmarthen', Carmarthenshire Antiquary, 22 (1986), 15-25.

${ }^{21} \mathrm{HMC}$, Calendar of the manuscripts of the most hon. the marquis of Salisbury (24 vols., London, 1883-1976), 10, p. 369.
} 
Wales. Salesbury was one of the translators who worked on this project along with Richard Davies, bishop of St Davids. The work proceeded slower than hoped, and by 1567 the pair had produced translations of the prayer book and New Testament only. Nevertheless, this was a considerable achievement, and one which once more illustrates the centrality of appeals to particularist history as a way of selling the new faith to a suspicious and obdurate Welsh public.

Davies and Salesbury were plugged into the antiquarian network centred on Archbishop Matthew Parker, whose researches into church history were designed to show how the Protestant faith 'is no new reformation of thinges lately begonne which were not before, but rather a reduction of the Church to the pristine state of olde conformitie'. ${ }^{22}$ Although Parker was principally concerned with the Anglo-Saxon roots of the church, he was also deeply interested in the British past. ${ }^{23}$ Davies and Salesbury were closely involved with the Welsh dimension to Parker's project, and corresponded with the archbishop about their antiquarian researches while they were engaged in the business of translating the Bible and liturgy. Davies wrote to Parker in March 1566 about some of the fruits of his historical labours, describing the 'conynewall warre ... bytwext the Brettayns (then inhabitauntes of the realme) and the Saxons, the Bryttayns beyng Christians and the Saxons pagans'. He indicated that the Britons and Saxons would eat and drink together when they parleyed about peace, but that after Augustine's mission the Saxons' Christianity was of such a sort as the Britons refused to dine with them 'bycause they corrupted with susp[er]sticion, ymages and ydolatrye the true religion of Christe, whyche the Bryttayns had reserved pure among them from the tyme of Kyng Lucius'. ${ }^{24}$ This message about the

\footnotetext{
22 John Foxe, Gospels of the Fower Evangelistes (London, 1571), sig. Ifiir.

${ }^{23}$ Matthew Parker, De Antiquitate Britannicae Ecclesiae \& Priuilegiis Ecclesiae Cantuariensis (London, 1572); Robinson, “'Darke Speech".

${ }^{24}$ Corpus Christi College (Cambridge), MS 114A, p. 493.
} 
corruption of (implicitly English) Catholicism and the purity of the (implicitly Welsh) brave Britons would resurface in perhaps the most powerful and effective amalgamation of Welsh historical polemic and reformist argument, Davies's Epistol at $y$ Cembru ('A Letter to the Welsh People') which prefaced the translation of the New Testament that appeared in 1567.

Davies's lengthy epistle was a text fashioned for more than one audience. It mixed some abstruse historical research and theological argument, designed perhaps with ministers and curates in mind, with direct addresses to the Welsh people about their splendid past, the perfidy of the English and the necessity of recovering their lost faith. It was redolent of the Galfridian tradition so beloved of the Welsh, and recalled the earlier scholarship of reformers like John Bale. It added a further layer of Welsh patriotic gloss to Geoffrey's narrative, but eschewed the medieval chronicler's broadly secular approach to focus on the religious antiquity and prestige of the Welsh.

The opening of the Epistol is a remarkable piece of prose which addresses the country directly: 'Awake thou now lovely Wales ... do not denationalize thyself, do not be indifferent, do not look down, but gaze upwards to the place thou dost belong, ${ }^{25}$ The immediacy of the address and the imploring appeal to national sentiment is striking, and recalls Salesbury's use of a similar mode in Oll Synnwyr two decades earlier. Indeed, there is evidence from contemporary marginalia on a copy of the New Testament in the Parker collection at Corpus Christi College, Cambridge, that this passage along with some others in the Epistol were in fact the work of Salesbury rather than Davies. ${ }^{26}$ When writing in the vernacular, Davies and Salesbury seem to have employed this direct, apostrophizing, technique to achieve a

\footnotetext{
${ }^{25}$ [Richard Davies and William Salesbury], Testament Newydd ein Arglwydd Iesv Christ (London, 1567), sig. aiii, translation in Albert Owen Evans, A Memorandum on the Legality of the Welsh Bible (Cardiff, 1925), p. 84.

${ }^{26}$ Roberts, 'Identity of “Anglican” Wales', 67 and nn. 52-3.
} 
sense of intimacy and a connection between author and reader/auditor. In this they were seeking to create communities among their readers and listeners who were not only bound together by a common language and history, but also by a common faith. This was an attempt to graft a confessional dimension onto a linguistic and historical community to create a Protestant Wales. There is also in Davies's (or perhaps Salesbury's) lines a pressing sense of urgency and necessity, a sense that souls were being lost without the benison of the translated scriptures. He ranged across millennia of the past to urge immediate action in the present.

The allied messages of national pride and spiritual renewal run through the Epistol as Davies provided the Welsh with a nationally-glossed version of the early British church and lauded the dignity and prowess of the Ancient Britons. Prominent here is the mission of Joseph of Arimathea which brought the message of Christ to the Britons from the fountainhead. Davies observed that Christianity did not gain general acceptance among the people, however, until the conversion of King Lucius in 180. Significantly, Lucius is presented in a Welsh milieu as 'Llês, son of Coel' ${ }^{27}$ Invoking Coel is also worthy of comment as Geoffrey of Monmouth had Coel's daughter, Helen (or Elen), marrying Constantius and giving birth to Constantine the Great. The 'Act in Restraint of Appeals' and the Henrician claim to empire were, in part, based upon an imperial lineage which ran back to the first Christian Roman emperor, who was also king of Britain. ${ }^{28}$ Although Davies acknowledged the variant scholarly interpretations about Lucius and the degree to which Rome had been involved in the Christianization of Britain, he emphasised the core point common to all and which

\footnotetext{
${ }^{27}$ Evans, Memorandum, p. 86.

${ }^{28}$ Richard Koebner, "The Imperial Crown of this Realm": Henry VIII, Constantine the Great and Polydore Vergil', Bulletin of the Institute of Historical Research, 26 (1953), 29-52; Antonia Harbus, Helena of Britain in Medieval Legend (Woodbridge, 2002), pp. 121-2.
} 
was particularly important for a Welsh audience: 'that the Britons received the undefiled and perfect religion of Christ' ${ }^{29}$

Davies went on to detail the antagonism between the Britons and the Saxons and the latter's Romish corruption by Augustine which he had described in his letter to Parker. ${ }^{30}$ Over time 'the edge of the sword' coerced the Britons into adopting the Saxon faith and departing from 'their own customary Christianity'. Davies emphasised the Britons' 'meanness and humiliation ... oppression and servitude' at the hands of the Saxons, drawing on the long-established anti-English discourse which again was designed to broaden the appeal of his message. However, the redemptive trajectory of the Historia and the Welsh Brut tradition was followed when Davies revealed to the Welsh the path to ultimate triumph and vindication which lay with the Welsh Tudors. This native line had reunified Britain by the Acts of Union and recovered the undefiled faith with the break from Rome. Drawing on contemporary ideas of cyclical revolutions in history, Davies again addressed his reader/auditor directly in passages which are worth quoting at length:

I have shown to thee thy pre-eminence and thy privilege of old, and thy humiliation and thy deprivation afterwards. Therefore, by proper meditation and recognition of thine own self thou shouldest be glad, and frequent thy thanksgiving to God, to her grace the Queen and to the Lords and Commons of the kingdom who are renewing thy privilege and honour ... Take it [the New Testament] in thy hand, grasp it and read it. Here shall thou see thy former condition, here wilt thou acquaint thyself with thy old faith, and the praiseworthy Christianity thou hadst before. Here wilt thou find the faith thou didst defend unto fire and sword, and for which thy religious and thy learned men were martyred long ago in the persecution. $^{31}$

This was a compelling combination of nationalist history, monarchism and reformed faith which had a profound impact on the nature and fortunes of Protestantism in Wales.

\footnotetext{
${ }^{29}$ Evans, Memorandum, p. 88.

${ }^{30}$ Ibid., pp. 90-3.

${ }^{31}$ Ibid., pp. 98, 103.
} 
It is difficult to untangle the significance of this view of Welsh history from other social and political factors in advancing the reformed cause, yet the very fact that Davies and Salesbury thought such an extended exercise in historicising of the faith for the people in an accessible manner was worthwhile, suggests that they were making capital from an idea of the Welsh past which had general currency among parishioners, and not just their ministers. It is also worth reflecting on the fact that this interpretation of history was not presented in an esoteric work of academic debate. It was placed at the opening of the New Testament itself, as a kind of contextualising primer for the Welsh better to understand the meaning of what followed. This historicising polemic would be present in all parish churches in Wales, and would have been accessible to the literate, but also, surely, promulgated by ministers as part of their readings and sermons. The closest parallel to this in England was Foxe's Book of Martyrs, but we may wonder whether Davies's message was not even more central to Welsh understandings of the reformed faith than Foxe's work was for English ones.

There is evidence that the positioning of the Welsh church in this long historical context elicited a positive response. The preface to Maurice Kyffin's 1595 translation of John Jewel's Apologia made particular reference to the utility of Davies's Epistol, describing it as a 'godly, learned letter to the Welsh' which led them to a 'renewal of the old Catholic faith and the light of Christ's Gospel'. Kyffin praised Davies's eloquence, adding that the letter 'undoubtedly ... would do great benefit for every Welshman that read it'. ${ }^{32}$ Importantly, Davies's 'Address' itself went on to be reprinted in a Welsh translation of Jewel's Apologia in 1671, and was later published separately, going into a third edition by the 1770 s. ${ }^{33}$ Evidently this was a standalone

\footnotetext{
${ }^{32}$ Garfield H. Hughes (ed.), Ragymadroddion, 1547-1659 (Cardiff, 1951), p. 92.

${ }^{33}$ [Charles Edwards], Dad Seiniad Meibion y Daran Sef Ail-Printiad o Lyfr Escob Juel a Elwir Deffyniad Ffydd Eglwys Loegr: ac o Epistol yr Escob Dafies at y Cembru (Oxford, 1671); Eluned Rees, Libri Walliae (2 vols., Aberystwyth, 1987), 1, p. 196.
} 
text and was almost certainly used as a didactic device. Yet perhaps the Epistol's significance lies not in the fact that such reinterpretation of history formed a separate strand of Reformation in Wales, but rather that it was placed at the heart of the translators' message. They produced an amalgam of history, faith, language and unalloyed patriotism which seems to have had a demotic as well as scholarly appeal.

\section{V}

Glanmor Williams has described how Protestantism made incremental but inexorable gains in Wales in the later sixteenth century, buoyed by the translations of Davies and Salesbury and their historical reframing. ${ }^{34}$ The publication of the complete Bible in translation by William Morgan in 1588 was a significant stage in this process. However, his magisterial volume did not possess the historical glosses of Davies's Epistol, although his Latin address to the Queen consistently referred to the Welsh as 'British' and the Welsh language as 'the British tongue'. ${ }^{35}$ Nevertheless, the close association between the church in Welsh and the Ancient Britons continued to be propagated in Welsh Protestant literature throughout the early modern period. For example, Maurice Kyffin's translation of Jewel's Apologia, Deffynniad Ffydd Eglwys Loegr, referred in its preface to the ancient faith of the Britons, while the work it translated was itself partly an exercise in uncovering the ancient British roots of the Church of England. 'We have planted no new religion', wrote Jewel, 'but only have renewed the old', a sentiment which perhaps suggests why this became one of the earliest theological works beside the Bible and prayer book to have been translated into Welsh. ${ }^{36}$ Kyffin, who was associated with antiquarians such as John Dee, William Camden and David Powel, had earlier produced a laudatory poem for

\footnotetext{
${ }^{34}$ Williams, Wales and the Reformation, pp. $216 \mathrm{ff}$.

${ }^{35}$ Evans, Memorandum, pp. 128-36.

${ }^{36}$ The Works of John Jewel ed. J. Ayre (4 vols., Cambridge, 1845-50), 4, p. 777.
} 
Elizabeth entitled The Blessednes of Brytaine. This praised Elizabeth as a 'blessed branch of Brutus Royall race', in the same stanza in which it thanked her for 'Graunting Christs Gospel in their country speche'. The close relationship between Welsh history and Welsh faith is once more prominent. A marginal note glossed this passage as 'Her maiestie princesse of Wales, where the inhabitants enioy Gods worde in their own language through the meere grace \& goodnes of her highnes'. ${ }^{37}$

In his panegyric to Elizabeth, Kyffin called on Welsh poets to praise the queen 'with waightie words used in King Arthurs daies', and the bardic material offers some suggestive evidence that ideas about the historicity of the Welsh Protestant church entered popular culture. ${ }^{38}$ Thomas Jones of Llandeilo Bertholau, Monmouthshire, for example, composed a poem at Christmas 1588 to give thanks for the full translation of the Bible. His composition drew on Davies's presentation of the early British Church, rehearsing many of the themes found in the Epistol. These included the baleful influence of Augustine on the primitive church, and the 'power of the Saxons' which suppressed the 'great schools of the Welshman' (Drwy nerth Saeson torrai lawr/Ysgolion mawr y Cymro'). ${ }^{39}$ Similarly, Huw Machno's poem to William Morgan of 1595 described how the true faith had been given to the Britons in their old language before it was lost to a long, cold blindness of Catholic error. Yet through the efforts of Morgan and the approbation of a Queen of Welsh descent, God had provided for a restoration of the things once lost, and had delivered them from Roman darkness by the light of the vernacular gospel. ${ }^{40}$

\footnotetext{
${ }^{37}$ Maurice Kyffin, The Blessednes of Brytaine (London, 1587), sig. B1v.

${ }^{38}$ Kyffin, The Blessednes of Brytaine, sig. B4.

${ }^{39}$ L. J. Hopkins and T. C. Evans (eds), Hen Gwndidau, Carolau a Chywyddau (Bangor, 1910), pp. 187-8.

${ }^{40}$ R. G. Gruffydd, 'Y Beibl a Droes i’w Bobl Draw' (London, 1988), p. 51.
} 
This Welsh language material underlines the importance of language and history in the cultural adaptation of the Reformation in Wales, yet we should recall that the ancient British church underwrote the historical arguments for the English Reformation also. English Protestant scholars from the early days of the break with Rome seized on the traces of the primitive church in Britain to defend the Reformation from allegations of novelty. This also proved to be a powerful and durable argument upon which the English church was based. Yet there was a potential problem of contemporary identities to deal with here in that English scholars were appropriating the church of a people whom they acknowledged had been cast into Wales and Cornwall by their Saxon ancestors; ancestors who had ultimately succumbed to Catholic error. The principal means of addressing this paradox seems to have been by ignoring it altogether and focusing rather on attacking papists. Even a work with a title such as Albion's England confronted the Catholics by conflating them with Augustine's Saxons who slaughtered the British monks at Bangor. The latter were described as 'Welsh-Britons' whose gospel was 'the primitive churchpractise of the trew faith'. ${ }^{41}$ Apparently the 'Welsh-Britons' could be presented fairly unproblematically as the spiritual ancestors of the English. Similarly, William Burghley's tract, 'England Triumphans', was, in fact, an antiquarian argument for spiritual independence from Rome based on the essential elements of the Brut including Brutus himself, the mission of Joseph of Arimathea, King Lucius and Queen Helena and the power, pre-eminence and glory of Britain. Burghley recognised the Welsh as the descendents of the ancient Britons, but elided this silently with English ecclesiastical independence under Elizabeth. ${ }^{42}$ Thomas Norton's historical exegesis, 'The V Periodes', often refers to Britain and England, but with little sense

\footnotetext{
${ }^{41}$ William Warner, A Continuance of Albion's England (London, 1606), pp. 382-7.

${ }^{42}$ TNA, SP12/75/55, 58.
} 
that these were problematic categories. Anthony Martin has shown how Norton saw England and Wales as 'the contemporary political institution of an aboriginal ethnic national identity' with a singular ecclesiastical history. ${ }^{43}$ As was the case with nationalised conceptions of history more generally, the English in the sixteenth century largely ignored their Saxon roots, in stark contrast to the Teutonomania of later periods. Tellingly, outside the circle of Matthew Parker, it was dissident Catholics who were most visible in linking the present English with their Saxon heritage. $^{44}$

Some writers did tackle the tension between ethnic origins and confessional identities. Antiquarians like John Inett and Isaac Basire argued that the partial conquest of Wales by Henry I and the supplication of the British church under its metropolitan at St Davids to the authority of Canterbury, along with the political incorporation of Wales into England under the Tudors, had 'united the British to the English church' ${ }^{45}$ In Thomas Norton's schema, a remnant of the true British culture survives in Wales, and it is a 'saviour chosen out of British stock' who effects both the reunification of the old polity, but also the recovery of the old religion. ${ }^{46}$ Political union was sufficient in most instances to gloss over national or ethnic discontinuity, and the fabrication of a common political identity accompanied the rediscovery of a British church in the sixteenth century. As the Shrewsbury poet Arthur Kelton put it shortly after the union, 'Now is it England, sometime called Wales', while imperial advocates like Protector Somerset in the 1540s could claim that the English had

\footnotetext{
${ }^{43}$ Anthony Martin, 'The End of History: Thomas Norton's "V Periodes" and the Pattern of English Protestant Historiography', in Christopher Highley and John N. King (eds), John Foxe and his World (Aldershot and Burlington, VT, 2002), p. 38.

${ }^{44}$ Benedict Scott Robinson, 'John Foxe and the Anglo-Saxons', in Highley and King (eds), John Foxe and His World, pp. 54-72; 77; Schwyzer, Literature, Nationalism and Memory, pp. 39-40; Kidd, British Identities, passim.

${ }^{45}$ Isaac Basire, The Ancient Liberty of the Brittanick Church (London, 1661), p. 25; Kidd, British Identities, pp. 120-1.

${ }^{46}$ Martin, 'The End of History', 48.
} 
become Britons - a construction used to underwrite the project of enforced union with Scotland in the 'Rough Wooing', which had gained ideological momentum from the recent Anglo-Welsh union. ${ }^{47}$ This erasure of any separate Welsh element of the new faith seems to be a feature of most English polemics on the subject. As Colin Kidd has observed, the mechanisms whereby a British past became an English present were rarely spelled out, yet 'somehow the English clersiy squared contradictory accounts of a predominantly Saxon nationhood with a British pedigree for the ecclesia anglicana' ${ }^{48}$

\section{VII}

Although issues of language and nationality bulk large in the narrative of the Church of England in early modern Wales, these were also bound up with doctrinal and theological struggle, as Catholic and puritan elements sought to appropriate and deploy their vision of the history of the church in Wales for particular ends. The corpus of contemporary Catholic literature on this subject is comparatively small, but it is clear that they too laid claim to the long pedigree of the Welsh to argue for the primacy of their faith and to denigrate the claims of antiquity by 'the new men' ( $y$ gwŷr newydd). Welsh Catholic exile Morys Clynnog reflected on the strength of Catholicism among the Welsh in a planned invasion project of 1575 , maintaining that the "consent and constancy in the true faith and religion of this Welsh nation is of very great antiquity, and is not to be despised for it may be proved from the writings of ancient and more recent authors'. ${ }^{49}$

A major problem for the Catholics in countering Protestant views of church history, of course, was that their access to the public sphere was highly circumscribed.

\footnotetext{
${ }^{47}$ Arthur Kelton, A Chronycle with a Genealogie Declaryng that the Brittons and Welshemen are Lineallye Dyscended from Brute (London, 1547), sig. biiii; Schwyzer, Literature, Nationalism and Memory, pp. 34-6.

${ }^{48}$ Kidd, British Identities, pp. 103, 120-1.

${ }^{49}$ Cleary, 'Dr Morys Clynnog's Invasion Projects', 309.
} 
They could not easily publish their treatises, and the problems caused by a lack of Catholic literature was commented on by Clynnog in 1568, when he claimed that the main cause of a falling away from the Catholic faith in Wales was 'the lack of books ${ }^{50}$ Nevertheless, it is clear that Catholics believed they had a superior claim to the Welsh past, and viewed the Protestant liberties with their history as a heinous perversion. Owen Lewis, originally of Llangadwaladr in Anglesey but an exile who became bishop of Cassano in Naples, told Mary Stuart's envoy that the Welsh and Scots needed to 'stick together, for we are the old and true inhibiters and owners of the isle of Britanny; these others be but usurpers and mere possessors' ${ }^{51}$ Clynnog argued for a different kind of religious continuity to the Welsh Protestants in a letter to Pope Gregory. He attributed the strength of Catholicism in Wales simply to the fact that the Welsh were 'the original inhabitants of that island, a people who retain ... the Catholic faith of their fathers' ${ }^{52}$ Similarly, Richard White, the Welsh seminary priest martyred at Wrexham in 1584 , was said to have died for his 'constancy for the faith of the old Britons, their [the Welsh's] dear progenitors' ${ }^{53}$

Perhaps the most interesting deployment of Welsh history for Catholic ends was to be found in Y Drych Cristnogawl (The Christian's Mirror) (1586-7). This was the first book to be printed on Welsh soil, although it had to be done clandestinely in a cave near Llandudno. Scholarship favours its author as Robert Gwyn of Llŷn, although the grammarian Gruffydd Robert and Sion Dafydd Rhys have also been mentioned. It is a discussion of the Four Last Things: Death, Judgement, Hell and Heaven, but is framed in accessible language 'in order to enable simple folk to

\footnotetext{
${ }^{50}$ Quoted in Williams, Wales and the Reformation, p. 253.

${ }^{51}$ T.F. Knox, ed., Letters and Memorials of William Cardinal Allen (London, 1882), p. 82.

${ }^{52}$ Paul Bryant-Quinn, “"To Preserve Our Language”: Gruffydd Roberts and Morys Clynnog', Journal of Welsh Religious History, 8 (2000), 22.

${ }^{53}$ Williams, Wales and the Reformation, p. 270.
} 
understand the book and benefit from it ${ }^{54}$ What is intriguing for our purposes is the way in which the opening section of the book echoes Richard Davies's Epistol. ${ }^{55}$ This section is addressed to 'the kind Welsh', and adopts a similar kind of direct engagement with the reader to that of Salesbury and Davies, and also rehearses the nature of early Welsh Christianity.

The preface shows some striking similarities with the Protestant vision of the Welsh confessional past and the repetition of key themes between the two suggests a common understanding of Welsh religious history with a broad popular resonance. The author refers to the mission of Joseph of Arimathea to Britain, where he was said to have converted many of the inhabitants. As might be expected, however, here we find a much more active role for the papacy in fostering learning and piety among the early Britons. Prominence is given to the agency of Pope Elutherius who, having received entreaties from Lês (Lucius) son of Coel, sent two 'apostles of the Welsh', Fagan and Wervan, to assist in the Christianising effort. The author of the Drych also appropriates Emperor Constantine, and his mother Elen, for the cause of the Church of Rome. He goes on to upbraid the Welsh for losing their faith and their language, principally blaming the anglicising gentry class in a polemic designed to wound the Protestant church in Wales through the gentry's sides.

There is evidence that ordinary Welsh Catholics as well as exiled polemicists saw their faith as historically rooted in Welsh soil. One interesting survival is an $a w d l$, a poem in traditional strict metre, which circulated in 1600-1. The author condemned the Protestants and the persecution of his co-religionists. He called for action against 'the spurious priesthood' and 'unlearned Scripturists', and gestured towards the historical underpinnings of the true faith as a justification for national conflict:

\footnotetext{
${ }^{54}$ Geraint Bowen, Welsh Recusant Writings (Cardiff, 1999), p. 36.

${ }^{55}$ Geraint Bowen (ed.), Y Drych Kristnogawl: Llawysgrif Caerdydd 3.240 (Cardiff, 1996), pp. 1-12.
} 
Rout them [Welsh Protestants] with the sword, you true Welsh of British blood, The murder of Jesus lies in the hearts of the Saxons. ${ }^{56}$

One could imagine such speech being placed in the mouth of a seventh-century Briton by a sixteenth century Protestant apologist!

An interesting sidelight on the Welsh Catholic view of British History can be found in the bitter dispute between the Welsh and English contingents at the English College in Rome during the 1570s. ${ }^{57}$ The differences arose largely because of the influence at the College of Morys Clynnog and Owen Lewis, who were seen excessively to favour Welsh students over their English counterparts. The Jesuit Robert Parsons described the split within the College as a 'nationall quarrel (as in colleges and universities is wont to ensue) betwene the Englishe and the Welche'. ${ }^{58}$ The Welsh seemed to have had a plan for establishing this as a British College, possibly even without any English students present. They were stymied in their efforts, however, and, after an acrimonious struggle it was the English who were placed firmly in charge and Clynnog and Lewis were overthrown. This split was not just about present-day tensions, however, as national divisions were exacerbated by differing interpretations of sacred history.

This question of historical interpretation and contemporary spiritual identity emerged after the discovery of a tombstone during the reconstruction of St Peter's basilica in the late 1570s. The English Catholics of Rome claimed the stone was that of Caedwalla, king of Wessex who had died while on pilgrimage in 689, as recorded

\footnotetext{
${ }^{56}$ TNA, SP15/8/127, discussed and translated in Roberts, 'Wales and the British Inheritance', pp. 34-5; Owen, Elizabethan Wales, p. 218; R. G. Gruffydd, 'Awdl Wrthryfelgar gan Edward Dafydd', Llên Cymru, 5 (1959), 155-63 and 8 (1964), 65-9; T. W. Hancock, 'A Strange Welsh Manuscript', ByeGones Relating to Wales and the Border Counties, 2nd ser., 6 (1899-1900), 50-3.

${ }^{57}$ This paragraph draws heavily on Jason A. Nice, "Being "British" in Rome: The Welsh at the English College', Catholic Historical Review, 92 (2006), 1-24, and Geraint Bowen, 'Apêl at y Pab Ynghylch Dilysrwydd Historia Regnum, Sieffre o Fynwy', National Library of Wales Journal, 15 (1967-8), $127-$ 46.

${ }^{58}$ The Memoirs of Father Robert Persons, ed. J.H. Pollen (London, 1906), p. 86.
} 
by Bede. The Welsh exiles, however, maintained that this was the tomb of Cadwaladr the Blessed, the last king of the Britons, and a key character in the Galfridian narrative. He had been given the revelation of the loss of empire by the Britons (and its subsequent recovery), and had abandoned his kingdom to go on pilgrimage to Rome where he had died, also in 689. According to Geoffrey's tale, when Cadwallader's bones were returned to Britain, so the descendants of the Ancient Britons would recover their lost patrimony. The Welshmen of the College were determined to fashion the discovery to fit their own historiographical predilections, as well as their immediate political purposes in claiming authority over the English in the College. They were unsuccessful, but the whole episode is revealing of the claims which Catholics had to the Brut tradition and their passionate defence of it in the face of English scepticism. It is also suggestive of how both Welsh Protestants and Catholics saw the early British church as an important component of their spiritual identities. The Welsh Catholics located Rome at the heart of their spiritual Britishness, and Cadwaladr's remains were located at the core of the True Church until, though the agency of the Pope, they could be returned to their homeland and restore the true British faith of Catholicism to its rightful dominion over the island.

\section{VIII}

The battle for the spiritual soul of Britishness was not simply waged between Welsh Catholics and Protestants. The small impulse of puritan sentiment in early modern Wales also sought to bolster its appeals to authority and claims to legitimacy by drawing upon the Brut tradition. A fairly lone voice for radical religious reform in 
Wales during the sixteenth century was John Penry of Breconshire. ${ }^{59}$ A Presbyterian with links to the Marprelate pamphleteers, Penry was a passionate advocate for reform in his native Wales, and focused on its stunted reformation in his pamphlets. The first of these, The Aequity of an Humble Supplication was presented to parliament in 1587 as part of a broader report on the spiritual condition of England and Wales. It was a trenchant attack on the poor state of religion there, with the blame being laid squarely on shoulders of the bishops. Penry suggested that the spiritual neglect of his countrymen might be a product of prejudice: 'as though we were contemned and not accounted of but as thrown into the most barren corner of the land, so thought unworthy to have the seed of God's word sowen amongst us'. To counter this he looked to place Wales at the centre of British religion through its historical primacy. He averred that it might grieve the Welsh less to be denied the gospel 'unless the same were the inheritance which our forefathers the Cymbrubrittons many hundred years agoe possessed in this lande'. He was invoking an original purity in Wales to underwrite the radical programme of reform he advocated there. Penry claimed that it was 'our divines in Wales' who had bravely resisted the 'proud friar' Augustine and the 'impes of that lifeless and brutish stock of Rome'. He went on to argue that the falling away into Catholic heresy was only a recent occurrence as the Welsh language had no oaths which swore on the mass, and that they had no words such as 'Candlemas' for holidays but rather 'the holy day of Mary'. From this linguistic evidence it was clear that such ceremonies were 'but yesterday, as it were, knowen to us', while 'ignorance and idolatry ... tooke such deepe roote in England, that it ran

\footnotetext{
${ }^{59}$ For more on Penry, see Glanmor Williams, 'John Penry: Marprelate and Patriot?', Welsh History Review, 3 (1966-7), 361-80; D. J. McGinn, John Penry and the Marprelate Controversy (London, 1966); John Gwynfor Jones, 'John Penry: Government, Order and the "Perishing Souls" of Wales', Transactions of the Honourable Society of Cymmrodorion 1993, 47-81; Claire Cross, 'Penry, John (1562/3-1593)', Oxford DNB.
} 
over our land also'. ${ }^{60}$ This was another markedly national gloss on the traditional British History for decidedly partisan ends. Penry claimed that his petition for reform was thus only the restoration of the 'inheritaunce of our fathers', so he attempted to present a radical call through a framework of patriotic antiquity. The claim of spiritual restoration particular to the Welsh was a message familiar from Davies's Epistol, but here was made to serve very different ends. As was often the case in early modern political and religious discourse, novelty was made palatable by presenting it in the garb of antiquity.

Penry was executed in 1593 for his increasingly radical opposition to the Church and state, and there was little evidence of puritan activism in Wales down to the civil wars of the 1640s. This period, however, saw a flowering of (often quite extreme) puritan opinion in the principality. As was the case with Penry, some of these Welsh controversialists presented their messages in ways designed to appeal to the historical consciousness of their countrymen. One of the most controversial churchmen to appear in Wales at this time was William Erbery of Merthyr Tydfil and Cardiff. Initially a beneficed minister in the Church of England, Erbery's increasingly separatist stance in the 1640 s and early 1650 s saw him branded as a Seeker. In a publication of 1652 Erbery argued that the Welsh were better gentlemen than the English, 'being pure Britaines', and were accounted by some to descend from the Jews. ${ }^{61}$ Rehearsing the litany of Lucius as the first Christian king, Constantine, 'a Britain or Welshman' as the first Christian emperor, and Britain as the first national church, he argued that a new liberty of worship (and the abolition of all church types)

\footnotetext{
${ }^{60}$ John Penry, A Treatise Containing the Aequity of an Humble Supplication... in the Behalfe of the Countrey of Wales (Oxford, 1587), pp. 41-2.

${ }^{61}$ William Erbery, Apocrypha (London, 1652), p. 2, bound with The Bishop of London (London, 1653). Bishop Ferrar had also described the Welsh as more gentle than the English in his Carmarthen sermon of 1550 , connecting their lengthy pedigree with innate qualities of gentlemanliness.
} 
would arise in Wales. ${ }^{62}$ Erbery had a sense of the Welsh as a chosen people, and although he viewed this primarily in terms of contemporary spirituality, it is suggestive of the continued attractions of the British History that he sometimes presented this with reference to Welsh antiquity and providential destiny. Erbery's was an apocalyptic vision in which the breaking down of established forms as a prelude to the last days would begin in Wales. Such apocalyptic history was in a venerable tradition which reached back to the early reformation and its Foxean reconfiguration. ${ }^{63}$ However, because of the comparative absence of a more radical strain in Welsh Protestantism, this seems to have the been first incorporation of Wales in such an eschatology.

An associate of Erbery who had links to Quakerism and a mystical millenarian strain of spirituality was Morgan Llwyd of Wrexham. Llwyd differed from many of his puritan contemporaries in that he wrote in Welsh in an effort to communicate his ideas about freedom of worship and spiritual authority directly to the people. Among his most famous compositions is Llyfr y Tri Aderyn ('Book of the Three Birds') which offers an allegorical view of church and state in the early 1650s. In the piece, Llwyd adapted the familiar Galfridian staples to argue for a unique connection between Wales and the early church which had ramifications for his countrymen's current spiritual plight. Possibly drawing on Davies's Epistol (as echoed in Y Drych Kristnogawl) he cited the reception of the gospel by 'Llês, the son of Coel', the tradition of Helen and Constantine as Britons, and claimed that 'Britons have been

\footnotetext{
${ }^{62}$ Erbery, Apocrypha, pp. 4-8.

${ }^{63}$ Katherine Firth, The Apocalyptic Tradition in Reformation Britain, 1530-1645 (Oxford, 1979); Richard Bauckman, Tudor Apocalypse (Appleford, 1978); Paul Christianson, Reformers and Babylon: English Apocalyptic Vision from the Reformation to the Eve of the Civil War (Toronto, 1978).
} 
steadfast unto death in behalf of the true faith' ${ }^{64}$ As in so many other cases cited here, Llwyd felt that the Welsh were among God's chosen people; their history had marked them as particularly favoured in the unfolding of the Lord's design on earth. Throughout his work, Llwyd draws on this understanding of the past to echo the conviction that the Welsh would have an important role to play in achieving the New Jerusalem which would rise from the corruption of the Caroline church, just as Salesbury and Davies had seen the Welsh as key in rescuing the pure religion from the dregs of Catholic corruption. As Llwyd reflected, 'out of the Isle of Britain will go forth, say many, fire and law, and hosts throughout the world'.

\section{IX}

The Welsh attachment to a nationalist view of their past produced a remarkably durable attachment to aspects of the Galfridian history which survived the critical attentions of Renaissance humanists. The story in England was somewhat different, with most antiquarians moving away from the British History as the sixteenth century progressed, and drawing a veil of rather embarrassed silence over its shaky (or non-existent) evidential base. This national difference in secular historiography did not map simply onto the approaches taken to religious history, as English Anglicans remained attached to the British foundations of their church into the eighteenth century. Yet it appears that the Welsh remained particularly devoted to their vision of the spiritual past as articulated by Richard Davies, and were less inclined to jettison the unconvincing accretions which fell away in the English

\footnotetext{
${ }^{64}$ Morgan Llwyd, 'The Book of the Three Birds', trans. L.J. Parry, in Cofnodion a Chyfansoddiadau Buddugol Eisteddfod Llandudno, 1896 (Liverpool, 1898), p. 213; E. Lewis Evans, Morgan Llwyd: Ymchwil i Rai o'r Prif Ddylanwaday a Fu Arno (Liverpool, 1931), pp. 13-16.
} 
context. $^{65}$ The blending of Geoffrey and the early British church seemed particularly attractive to those Welsh men and women of a royalist high church disposition. What was coming to be seen as a rather fabular romance in other circles enjoyed new vitality in Wales through the production of a literary classic in 1716, Drych y Prif Oesoedd (Mirror of the Early Ages) by the churchman, Theophilus Evans. Here was a patriotic defence of the Galfridian tradition in all its naïve majesty: Joseph of Arimathea even preached to the Britons in Welsh! Evans acknowledged that his account of the early dissemination of the gospel in Britain was questionable in places, but justified its rehearsal on the basis of tradition and usage. The Welsh rejected the historiographical scepticism of the English and Scots and clung fast to a view of the past which placed them at the centre of epochal developments and afforded them a privileged religious position not matched in the social, economic or political spheres of British life. As Geraint Jenkins has put it, 'Although the historicity of the Brut had come under heavy fire from the sixteenth century onwards, Geoffrey's romantic farrago ... stubbornly maintained its lustre in Wales' ${ }^{66}$

Elements of the Galfridian narrative were to remain important for Welsh identity into the nineteenth and even twentieth centuries as it became incorporated into the romantic tradition. It might be easy to see this as a 'reinvention' of national identity, a reworking of hoary myths in an age of fabricated antiquities, but this would be to miss the very real polemical service the tradition of the British church did in Wales during the Reformation. Yet this too was built upon older foundations which stretched back to the vaticinatory traditions of the Dark Ages. Constant in all these recyclings of the Brut were the desire to place the Welsh as God's elect at the centre

\footnotetext{
${ }^{65}$ Spurr, 'A Special Kindness for Dead Bishops', p. 324, n. 53. For developments in religious historiography in the later seventeenth and early eighteenth centuries, see Justin Champion, The Pillars of Priestcraft Shaken (Cambridge, 1992); Kidd, British Identities, pp. 99-122.

${ }^{66}$ Geraint H. Jenkins, Literature, Religion and Society in Wales, 1660-1730 (Cardiff, 1978), p. 219.
} 
of the narrative, to emphasise the primacy and continuity of their faithfulness, and to provide them with an aspirational trajectory of a return to former glories. Richard Davies and William Salesbury were very effective in moulding and mobilising these elements for the reformed faith, although moderate Protestantism did not have an unchallenged claim to the Welsh past. Welsh Catholics and nonconformists were also keen to demonstrate the historical foundations upon which their faith was built, but they had only limited access to the machinery needed for popularising their positions among the wider public. The Protestant establishment in Wales could draw on the resources of the state to spread the message of the historicity of the faith through press and pulpit.

The ancient British church had a greater patriotic appeal for the Welsh than it did for the English, yet its polemical deployment did not lead to any movement for separation from England, but rather to a closer integration of Wales within the Protestant British state. Such a discourse would continue to have a currency, particularly in Anglican circles, down to the modern era. The editorial of the first edition of $Y$ Brython (The Briton) by the Anglican D. Silvan Evans addressed its readers 'not only as Welshmen, but also as Britishers or Britons, that is as members of the British state, and as members of the British church' ${ }^{67}$ This would have been music to the ears of any Elizabethan Protestant, and was a testament to their success in cementing Wales within the larger polity using the resilient compound of history, faith and patriotism.

\footnotetext{
${ }^{67}$ Quoted in Paul O'Leary, 'The Languages of Patriotism in Wales, 1840-80', in Geraint H. Jenkins (ed.), The Welsh Language and Social Domains in the Nineteenth Century, 1801-1911 (Cardiff, 2000), p. 546.
} 